\title{
超電導限流器の短絡電流計算への組込みと設置点に関する検討
}

\author{
正員永田真幸 (電力中央研究所) \\ 正員田中和幸 (電力中央研究所)
}

Short Circuit Current Calculation Method and FCL Location Selection Method of Large-Scale Power System incorporating Superconducting Fault Current Limiters

Nagata Masaki, Member, Tanaka Kazuyuki, Member (CRIEPI)

\begin{abstract}
Maximum short circuit current of modern power system is becoming so large that circuit breakers are not expected to be able to shut down the current in near future. Fault Current Limiter (FCL) is supposed to be an effective solution of this problem and recent progress of superconductivity technology and power electronics makes it possible to develop current limiting type FCL such as diode-bridge type FCL. Current limiting type FCL limits the current through the FCL and its equivalent impedance is not constant and depends on fault location, operating point of power system and the limit of the current through FCL. In this paper, a method to incorporate such FCL into short circuit current analysis is proposed. Also, an efficient method to find location of FCLs suitable to suppress short circuit currents of more than one fault locations is developed. The efficiency and effectiveness of these methods are shown by numerical examples.
\end{abstract}

キーワード : 哣絡電流計算, 限流器

\section{1. はじめに}

電力系統では，近年の需要增に対応するために大規模 化，連系強化が行われてきている。これらの方策は系統 の供給力向上には效果的である反面，系統事故時に短䅂 電流を大きく堌大させる原因ともなっている。その結果， 今後, 短絡電流が現状の遮断器定格遮断電流を上回る可 能性があることが指摘されており，何らかの対策を講じ る必要がある。その一つとして限流器の導入による短絡 電流の抑制が検討されている。

近年の超電導技術の進展を背景として，これを利用し た超電導限流器の開発が進められている。基幹系統への 超電導限流器の導入を考える場合, 第一にその短絡電流 抑制効果を評価する必要がある。そのための手法として 短絡電流計算が挙げられるが、これはいわゆる故障計算 の一種であり，対称座標法をベースとした解析手法が従 来より主流となっている(1)。そのため，(1) 電流波形は 正弦波である,(2) 遮断器が動作する事故発生後 2,3 波 目以降の時間領域を解析の対象とする，の2 点を仮定し た計算となる。超電導限流器に関して，これまでの検討 で事故発生後 2,3 . 波目以降では, 限流動作が完了してい ることが明らかにされており(2)，この時間領域での短絡 電流計算による解析が妥当であると考えられる。 超電導限流器には样々な種類があるが(3), 短絡電流計算
の適用を考えると以下の 2 種類に大別することができる。 定インピーダンス型 動作時に設置点に固定のインビー ダンスを発生させるタイプ

電流制限型 動作時に限流器の通過電流を一定值で制限 するタイプ

この 2 種の超電導限流器の動作パラメータ(i)のうち, 短絡電流計算において重要となるパラメータは，定イン ピーダンス型については，限流動作完了時に出現するイ ンピーダンスであり，電流制限型については，動作時の 通過電流の上限值（制限電流）である。

制限電流が指定される電流制限型限流器は，系統条件 によって等価インピーダンスが変化するのに対し，従来 の短絡電流計算ではインピーダンスが固定されたネット ワークを解析の対象としており，このような限流器を扱 うことはできなかった。

また，限流器の実用化を系続の計画面から見た場合，系 統のどこに限流器を設置すれば短絡電流を効果的に抑制 できるか，の検討が不可欠となる。単一の事故点でのみ， 短絡電流の抑制が必要な場合には簡単に解を得ることが できるが，複数の事故点での短絡電流の抑制が求められ る場合には，短絡電流計算レベルで適切な設置点を選定 する手法が必要になる。

このような短嵞電流の低隇上系統の静的な安定性(電 生安定性)について系統棈成面から検討を行った例として 
文献 ${ }^{(5)}$ があるが，本文献では常時の系統インピーダンス 変更による短絡電流低隇が考虑されているのに対し, 超 電導限流器は「常時のインピーダンスは(ほぼ)0であり, 事故発生と同時に (速やかに) 限流に必要なインピーダン スを発生し，事故除去後は速やかに常時状態に復带する」 という特性の実現を目指して開発が進められておりっこ のような動作特性を考慮した検討が必要と思われる。ま た，電流制限型のような系統条件によって等価インピー ダンスが変化するタイプの限流器の扱い方も与えられて いない。

以上のことから，本稿では以下の計算を効率よく行な う手法について述べる。

・電流制限型限流器に対応した短絡電流計算

-超電導限流器の動作特性を考慮した，特に複数の事 故点に関して短絡電流の抑制が必要な場合の限流器 の設置点の算出

\section{2. 電流制限型限流器の短絡電流計算への組み込み}

$\langle 2 \cdot 1\rangle$ 電流制限型限流器等価インピーダンスの計算法 短絡電流計算で, 電流制限型限流器の動作を模擬するに は，限流器の通過電流を制限電流と等しくするような限 流器の等価インピーダンスを設置点に挿入すればよい。 この等価インピーダンスが得られれば，従来の短絡電流 計算手法を用いて, 電流制限型限流器がある場合の短絡 電流計算を行なうことができる。

限流器の設置点として，系統内のブランチおよびノー ドの母線連絡線（以下，母連と呼ぶ）の2 通りを考虑す る。また，式展開の簡単化のため，想定事故として 3 相 短絡（3LS）のみ考虑する。事故として非対称故障を想 定した場合，一相または二相の限流器のみが動作し，線 路定数が不平衡となるため計算が複雑となるが，この場 合でも対称座標法を用いて計算が可能であることが示さ れており ${ }^{(6)}$ ，本稿に述べる手法は非対称故障にも応用が 可能であると考えられる。

$\langle 2 \cdot 1 \cdot 1\rangle$ ブランチ設置の場合 3LS 事故を仮定し た場合の短絡電流計算では系統の正相回路のインピーダ ンスが必要となる。系統の健全時, 限流器がない場合の 3LS 事故時, 限流器が動作した場合の 3LS 事故時の正相 回路をそれぞれ，图 1 (a)，(b)，(c) で表す。限流器動 作を模擬するには，図 1 (c) の回路に扔いて $k-l$ 間の電 流の大きさが限流器制限電流 $I_{L}$ と等しくなるように，限 流器等価インピーダンス $\Delta Z$ を求めればよい。

図 1 (c) の回路は図 1 (d) と（e）の回路を重标合わせ たものである。なぜならば，図 1 (d) の回路は図1(b) の回路と等価であり, $k-l$ 間の電流は, 限流器がない場合 の事故時の $k-l$ 間の電流 $I_{N}$ と等しくなるからである。つ まり， $\Delta Z$ は図 $1(\mathrm{e})$ の回路の $k-l$ 間の電流が $I_{L}-I_{N}$ となるように決めればよい。

図 1 (e) で $k, l$ から左側の等価インピーダンス $Z_{R k l}$ は，図1(b)のそれと同じであるので，図 1 (b) の回路
での $k-l$ 間のインピーダンスを $Z_{E k l}$ とすると，

$$
\begin{aligned}
Z_{R k l} & =\frac{Z_{(s)} Z_{E k l}}{Z_{(s)}-Z_{E k l}} \cdots \ldots \\
Z_{E k l} & =Z_{k k}^{(b)}+Z_{l l}^{(b)}-2 Z_{k l}^{(b)}
\end{aligned}
$$

となる。ただし， $Z_{(s)}$ は限流器設置ブランチ $s$ のンピー ダンス, $Z_{k l}^{(b)}$ は図 1 (b) の回路のインピーダンス行列の $(k, l)$ 要素である。図 1(e) で $k-l$ 間の電流は

$$
\Delta I=-\frac{I_{N} \Delta Z}{Z_{R k l}+Z_{(s)}+\Delta Z}
$$

となるので，以上から，

$$
\begin{aligned}
I_{L} & =I_{N}+\Delta I \\
& =\left(1-\frac{\Delta Z}{Z_{R k l}+Z_{(s)}+\Delta Z}\right) I_{N}
\end{aligned}
$$

となる。限流比 $\left(=I_{L} / I_{N}\right)$ を $\alpha$ とおくと,(4) 式右边 の（）内が $\alpha$ と等しけれげよいので,

$$
\begin{aligned}
\Delta Z & =\frac{1-\alpha}{\alpha}\left(Z_{R k l}+Z_{(s)}\right) \\
& =\frac{(1-\alpha) Z_{(s)}^{2}}{\alpha\left(Z_{(s)}-Z_{k k}^{(b)}-Z_{l l}^{(b)}+2 Z_{k l}^{(b)}\right)} \cdots \cdots
\end{aligned}
$$

となる。

ここで, 図 1（b）の回路は図 1（a）の回路でノードi を接地した回路であるので, $Z_{k l}^{(a)}$ を図 1(a)の回路のイ ンピーダンス行列の $(k, l)$ 要素として，

$$
Z_{k l}^{(b)}=Z_{k l l}^{(a)}-\frac{Z_{k i}^{(a)} Z_{k j}^{(a)}}{Z_{j i}^{(a)}}
$$

となる(7)。

したがって $\Delta Z$ は

$$
\begin{aligned}
\Delta Z & =\frac{(1-\alpha) Z_{(s)}^{2}}{\alpha\left(Z_{(s)}-Z_{k k}^{(a)}-Z_{l l}^{(a)}+2 Z_{k l}^{(a)}+Z_{d}\right)} \\
Z_{d} & =\frac{\left(Z_{k i}^{(a)}-Z_{l i}^{(a)}\right)^{2}}{Z_{i i}^{(a)}}
\end{aligned}
$$

となる。（7）式により，限流器設置点の非設置時の電流 $I_{N}$, 健全時のネットワークのインピーダンス $Z_{i j}^{(a)}$ お び限流器制限電流 $I_{L} よ り$, 限流器の等価インピーダンス

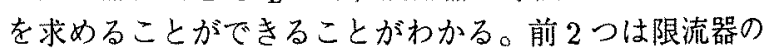
ない場合の短絡電流計算を行うことで得ることができる ので，限流器のない場合の短絡電流計算を行えば，ごく 簡単な計算で等価インビーダンスを算出できる。

さて, (5) 式は $I_{F}$ を非設置時の短絡電流として, 以下 のように変形できる。 


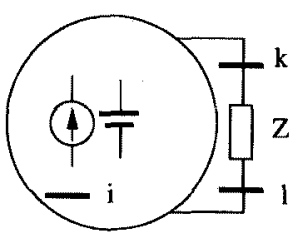

(a) 湕全時

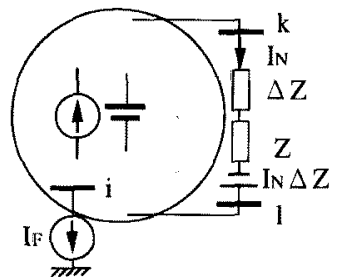

(d) （b）と等醉な回路

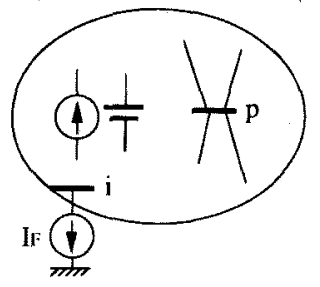

（f）短絡時（陆流器なし）

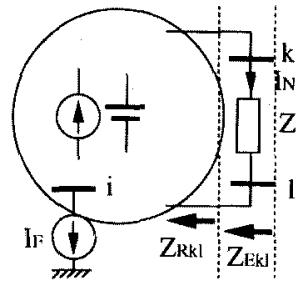

（b）短絡㖫（限流器なし）

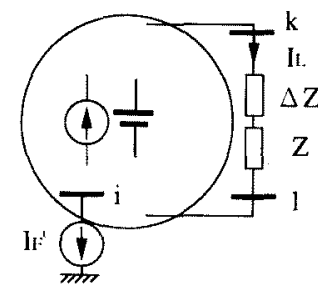

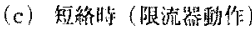

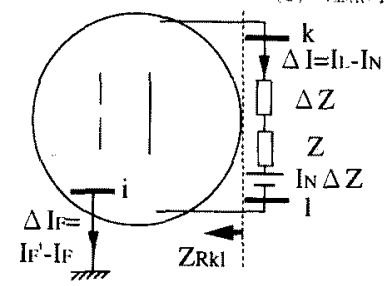

(e) (c) と(d) O㾏分回路

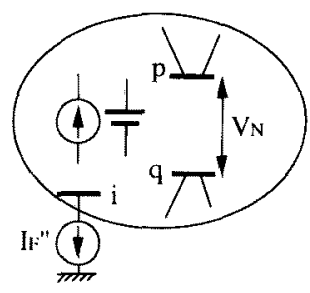

（g）知絡将（1!線分踓）

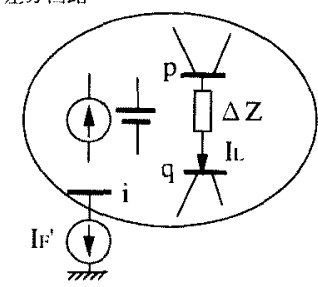

(h) 知絡标（限流器動作）

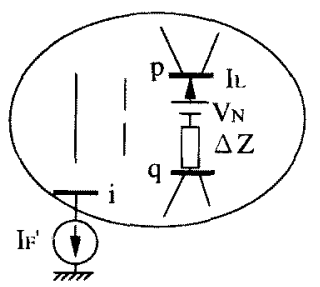

(i) (g) と(h) の登分回路

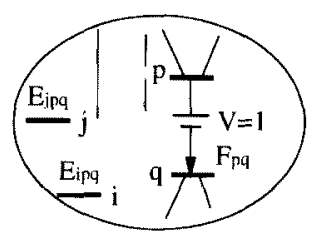

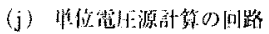

図 1 正相回路

Fig. 1. Positive Sequence Circuits

$$
\begin{aligned}
I_{L} & =I_{N}+\frac{Z_{k k}^{(b)}+Z_{l l}^{(b)}-2 Z_{k l}^{(b)}-Z_{(s)}}{Z_{(s)}^{2}} I_{L} \Delta Z \\
& =\frac{Z_{i k}^{(a)}-Z_{i l}^{(a)}}{Z_{(s)}} I_{F}+\frac{Z_{k k}^{(b)}+Z_{l l}^{(b)}-2 Z_{k l}^{(b)}-Z_{(s)}}{Z_{(s)}^{2}} V_{L} \\
& =A_{i s} I_{F}+B_{s s} V_{L} \ldots \ldots \ldots \ldots \ldots \ldots \ldots \ldots \ldots
\end{aligned}
$$

すなわち, 限流器動作時の設置ブランチの電流は, 限 流器なしの場合の電流に，事故点を接地した回路（図 1 (b)）で設置ブランチに $V_{L}\left(=I_{L} \Delta Z\right)$ の電圧源を置いた 場合の設置点の電流 (7)を加えたものとなる。前者の計算 では健全時の回路（図1（a））のインピーダンスを用い, 後者の計算には事故点を接地した回路（図 1 (b)）のイ ンピーダンスを用いることに注意されたい。

系統内の複数の電流制限型限流器が動作する場合, ブ ランチ $s$ をード $k-l$ 間, ブランチ $t$ をノード $m-n$ 間, $Z_{(s)}, Z_{(t)}$ をそれぞれ，ブランチ $s, t$ のインピーダンス

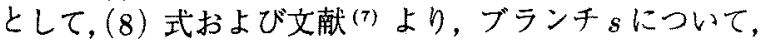

$$
\begin{aligned}
I_{L s}= & A_{i s} I_{F}+\sum_{t} B_{s t} V_{L t} \ldots \ldots \ldots \ldots \\
& t \in \text { 限流器設置ブランチ } \\
A_{i s}= & \frac{Z_{i k}^{(a)}-Z_{i l}^{(a)}}{Z_{(s)}} \\
B_{s t}= & \frac{Z_{k m}^{(b)}-Z_{k n}^{(b)}-Z_{l m}^{(b)}+Z_{l n}^{(b)}}{Z_{(s)} Z_{(t)}}-\frac{\delta_{s t}}{Z_{(s)}}
\end{aligned}
$$

となる。したがって，(9) 式を連立方程式として $V_{L s}$ に ついて解けば, $\Delta Z_{(s)}=V_{L s} / I_{L s}$ として，複数の電流制 限型限流器が動作する場合での個々の限流器の等価イン ピーダンスを計算することができる。

$\langle 2 \cdot 1 \cdot 2\rangle$ 母連に設置した場合 電流制限型限流器を 母連に設置する場合，母連をごく小さなインピーダンス を持つブランチとして扱えば，前節に述べた定式化を適 用することで近似的に計算できる。しかしながら，母線 構成が変化する毎にY 行列に関する計算が必要となり， 効率的な計算法とはいえない。以下に限流器を母連に設 
置した場合の効㳬的な計算法を述べる。

筆者らは既に，ブランチの投入，ノードの分割を行っ た際にZ行列要素の修正分を効率的に求める手法を開発 している(7)(8)。母連に設置された限流器の等価インビー ダンスはこれらの手法を応用することで效率的に計算 することができる。すなわち，いったん母連を境として ノードを分割し，分割の結果得られる2つのノード間に， ブランチ電流が限流器制限電流と等しくなるようなイン ピーダンスを持つブランチを投入する，として計算すれ ばよい。

3LS 事故時のノード分割前，ノード分割後，限流器動 作時の正相回路をそれぞれ四 $1(\mathrm{f}),(\mathrm{g})$ ，(h) で表す。限 流器動作を模擬するためには，図1(h) の回路において $p-q$ 間の笔流の大きさが限流器制限電流 $I_{L}$ と等しくなる ように，限流器等価インピーダンス $\Delta Z$ を求めればよい。 ここで，図 $1(\mathrm{~g})$ の回路と図 $1(\mathrm{~h})$ の回路の差分をと ると，图1（i）の回路となる。 $\Delta Z$ は，この回路のp-q間 の電流が $I_{L}$ となるように洪めればよいことになる。

図1（i）において，

$$
V_{N}=-I_{L}\left(Z_{p p}+Z_{q q}-2 Z_{p q}+\Delta Z\right)
$$

となるので，これと文献（5）より，

$$
\begin{aligned}
\Delta Z & =-\frac{V_{N}}{I_{L}}-Z_{p p}^{(g)}-Z_{q q}^{(g)}+2 Z_{p q}^{(g)} \\
& =-\frac{I_{N}}{I_{L} F_{p q}}-Z_{p p}^{(g)}-Z_{q q}^{(g)}+2 Z_{p q}^{(g)}
\end{aligned}
$$

となる。 $Z_{k l}^{(g)}$ は図 $1(\mathrm{~g})$ の回路のインピーダンス行列の $(k, l)$ 要素であり, 文献 $(5) よ り$,

$$
Z_{i j}^{(g)}=Z_{i j}^{(a)}-\frac{E_{i p q} E_{j p q}}{F_{p q}}
$$

として得ることができる。 $I_{N}$ は，限流器の無い場合に 事故時に母連を流れる電流， $F_{p q} ， E_{i p q}$ はそれぞれ，図 1 (j) の回路で $p-q$ 間を流れる電流，ノードiの電圧で ある。

（12）式の右辺の変数は全て, 図 1 (j) の回路での草 位電圧源の電位計算を一回行うことで得ることができる。 すなわち、この単位電圧源の電位計算を一回行うだけで, $\Delta Z$ の值を得ることができ，ブランチに設置した場合と 同様に，限流器等価インピーダンスを効率よく求めるこ とができる。

系統に電流制限型限流器が設置された場合の 3LS 事故 時の短絡電流および電流分布を求めるための処理の流れ 図を図 2 に示す。影のついている部分が電流制限型限流 器のための処理である。

〈2・2〉 数值例 モデル系統として，図 3 に示寸 New England 系統を用いる。この系統で短絡電流が最大 となる事故点ノードは16であり, 無負荷時の短絡電流は $28.052[\mathrm{pu}]$ となる。

ここで, 限流器の設置パターンとして

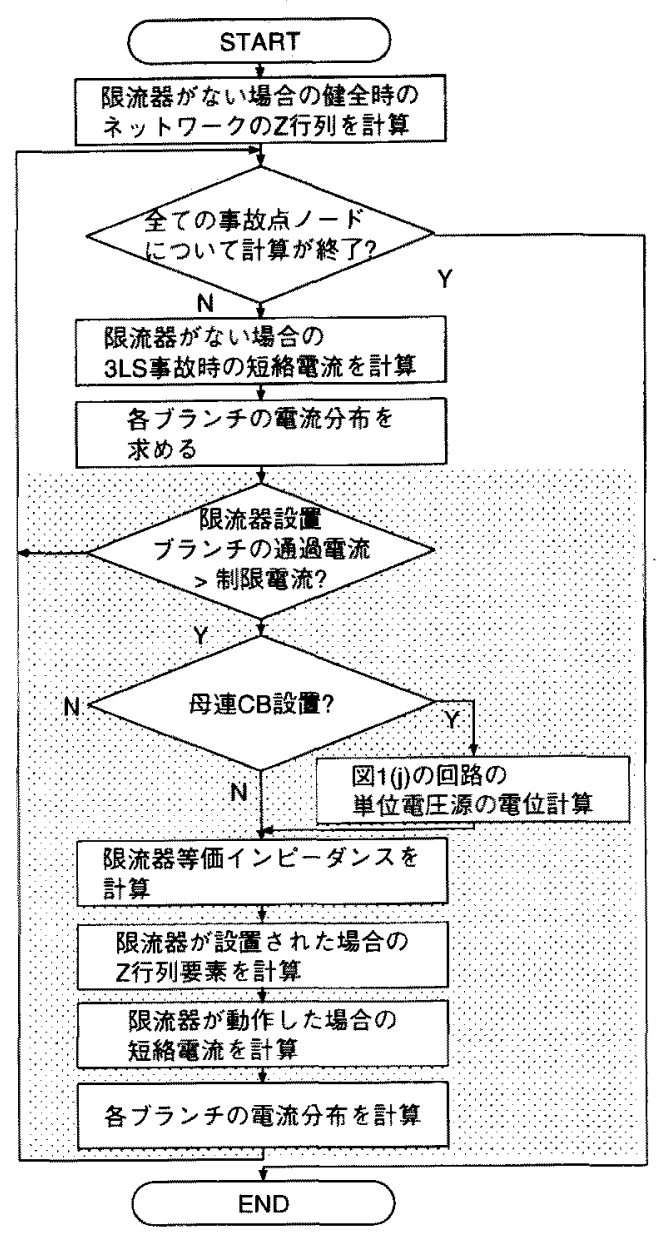

図 2 電流制限型限流器を考髟した 短絡電流計算の流れ図

Fig. 2. Flow Chart of Short Circuit Current Calculation Incorporating Diode-Bridge Type FCL

Case 1 ブランチ $A$ に設置

Case 2 ブランチ $B$ に設置

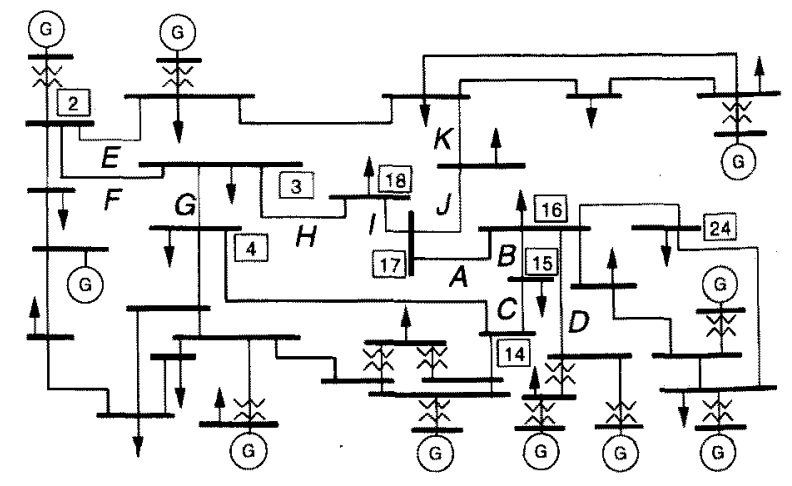

図 3 New England 系統

Fig. 3. New England Power System 
Case $3 A$ と $B$ の両方に設置

の3通りを考える。

〈2・1〉節に述べた方法で計算した，各 Caseでの短絡電 流, $A$ および $B$ の電流, 限流器等価インピーダンスを表 1 に示す。ただし，限流器は等価インピーダンスとして リアクタンス分のみを持つものとし，限流器の制限電流 は，簡単のため，いずれのケースでも非設置時の設置点 の電流から $2.0[\mathrm{pu}]$ 引いた値とした。

表 1 より，〈2・1〉節に述べた力法で限流器動作時の電流 分布が正しく得られていることがわかる。 $A$ と $B$ の片側 にしか限流器を設置しない場合 (Case 1 および Case 2) では，限流された電流の一部が限流器のないブランチか ら回り込むため, 限流器設置ブランチでの電流の隇少に 比べ，短絡電流の減少值が小さくなっている。また，電 流回り込みのため, 限流器非設置ブランチでは短絡時の 電流がかえって增加している。これに対し, Case 3 では 電流の回り込みが発生しないため, 限流器設置ブランチ での電流隇少值の和 $4.0[\mathrm{pu}]$ と同じたけ短絡電流が減少 している。

\section{3. 限流器の設置点選定法}

〈3.1〉 設置点選定の考え万本節では，特に複数の 事故点に関して，短絡電流の抑制が必要な場合に，どこ にどれだけの等価インピーダンスを持つ限流器を設置す ればよいかの算出法について迹べる。電流制限型限流器 の制限電流はく2・1〉節に述べた方法を応用して，等洒イン ピーダンスから算出することができるので，ここでは限 流器の等価インピーダンスのみを考虑し, 制限電流は考 慮しない。また，限流器の等価インピーダンスは正の值 のみを取る（抵抗またはリアクタンス）とする。

限流器として超電導限流器を考えた場合, 事故時のみ 限流インピーダンスを発生することが期待できることか ら，文献(5)で考慮されている電圧安定性への影響は十分 小さいと考えられる。そのため, 設置点選定に当たって は, 短絡電流の低滅のみを考慮した。

超電導限流器は導入コストの観点から, 設置点数 (台 数)をなるべく小さくすることが求められると考えられ る。また，製造コストや製造技術，過電圧の㧕制などの 観点から，限流器等価インピーダンスには制約 (上限) が 設けられ，さらに必要な限流性能を確保した上で，等価 インピーダンスをなるべく小さくすることが求められる と考えられる。

以上の議論から，主として導入コストを考慮した場合， 限流器の設置点および必要となる等価インピーダンスを 求めるには以下の最適化問題を解けばよいと考えられる。 目的関数 限流器の設置点 (設置台数) を最小化し，その 上で限流器の等価インビーダンスの総和を最小にする 制的条件 限流器等価インピーダンスの上限内で, 全て の事故点で短絡電流をある決められた值以下とする ここで，限流器の設置点（設置台数）をなるべく少な
くすることに着目すれ洛，“短絡電流の低減に最も効果的 な設置点”から 1 籄所ずつ設置点を選定していくという 方法で十分最適解に近い解が得られると考えられる。以 下では，この考えにしたがった限流器の設置点選定手法 について述べる。

$\langle 3 \cdot 2\rangle$ 短絡電流の低減に最も効果的な設置点の選定法 “短絡電流の低減に最も效果的な設置点”を言い替えると 以下のようになる。

-全て, ないし最も多くの事故点に対して, 限流器を 設置することで短絡電流を決められた值以下に抑え る事ができる点

・上記に該当する設置点が複数ある場合には，その中 で限流器の必要等価インピーダンスが最も小さな值 となる点

ここで，ある設置点（ノード $k-l$ 間のブランチとする）

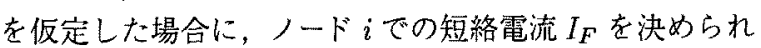
た值 $I_{L}$ にするために必要な限流器の等価インピーダン ス $\Delta Z$ は以下のように求めることができる。

まず, $k-l$ 間のブランチに $\Delta Z$ のインピーダンスを直 列に付加することと, 同じブランチに $Z_{p}$ のインビーダ ンスを並列に付加することが等価であるとすると，当該 ブランチのインピーダンスを $Z_{(s)}$ として，

$$
Z_{p}=-\frac{Z_{(s)}\left(Z_{(s)}+\Delta Z\right)}{\Delta Z}
$$

であり,このときノードiの駆動点インピーダンス $Z_{i i}$ の 変化量は

$$
\begin{aligned}
\Delta Z_{i i} & =-\frac{\left(Z_{i k}-Z_{i l}\right)^{2}}{Z_{k k}+Z_{l l}-2 Z_{k l}+Z_{p}} \\
& =-\frac{C_{2}}{C_{1}+Z_{p}} \cdots \cdots \cdots \cdots
\end{aligned}
$$

となる(7)。ただし $Z_{i j}$ はインピーダンス行列の $(i, j)$ 要 素である。事故として 3 相短絡を仮定すると短絡電流の 変化量 $\Delta I_{F}$ は， $V_{i}$ をノード $i$ の健全時の電压として,

$$
\begin{aligned}
\Delta I_{F}= & \frac{V_{i}}{Z_{i i}+\Delta Z_{i i}}-\frac{V_{i}}{Z_{i i}} \\
& \frac{V_{i}}{Z_{i i}} \frac{C_{2}}{\left(C_{1}+Z_{p}\right) Z_{i i}-C_{2}}
\end{aligned}
$$

となる。 $\Delta I_{F}=I_{N}-I_{F}$ となればよいので，

$$
Z_{p}=\frac{I_{L}}{I_{L}-I_{F}} \frac{C_{2}}{Z_{i i}}-C_{1}
$$

となりっこれを

$$
\Delta Z=\frac{Z_{(s)}^{2}}{Z_{(s)}+Z_{p}}
$$

に代入すれば，必要となる等価インピーダンスが得られ る。ここでは限流器をブランチに設置する場合を仮定し たが，母連に設置する場合も同様に計算できる。 
表 1 限流器設置パターンによる比較

Table 1. Comparison between FCL configurations

\begin{tabular}{|c|c|c|c|c|c|c|c|}
\hline \multirow{2}{*}{ 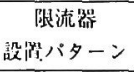 } & \multirow[t]{2}{*}{ 短絡留流 } & \multicolumn{4}{|c|}{ ブランチ丽流 } & \multicolumn{2}{|c|}{ 限流器等佂リアクタンス } \\
\hline & & & $A$ & & $B$ & $A$ & $B$ \\
\hline 排没符 & 28.052 & 9.470 & & 5.887 & & - & - \\
\hline Case 1 & $(-1.046)$ & 7.470 & $(-2.000)$ & 6.841 & $(+0.934)$ & j0.01478 & - \\
\hline Case 2 & $(-0.811)$ & 10.659 & $(+1.189)$ & 3.887 & $(-2.000)$ & - & jo. 03542 \\
\hline Case 3 & $(-4.000)$ & $7: 470$ & $(-2.000)$ & 3.887 & $(-2.000)$ & j0.03291 & j0.07304 \\
\hline
\end{tabular}

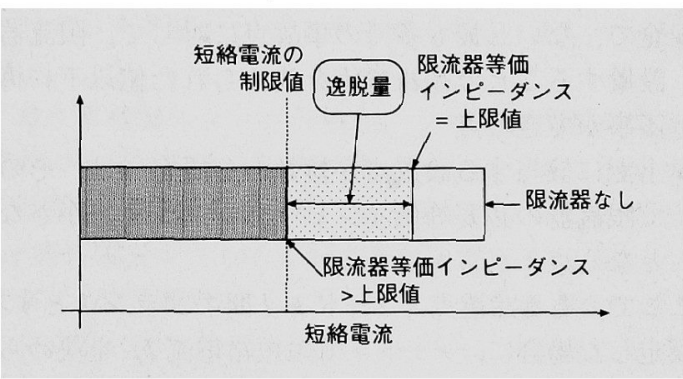

図 4 限流器等価インピーダンスに 上限がある場合の逸脱量

Fig. 4. Deviation of Fault Current from Limitation

さて, 上記の手法で必要となる限流器等価インピーダ ンスを計算すると，その値が負となる場合がある。これ は設置点に，どんなに大きな正の等価インピーダンスを 持つ限流器を設置しても，すなわち事故中に設置点ブラ ンチを開放するとしても，短絡電流を決められた值まで 抑えることができない場合である。

以上に述べた方法で, 考えられる限流器の設置点につ いて必要となる等価インピーダンスを算出することで, 值の正負, 大きさから, どの設置点がネットワークの特 性上, 最適な設置点であるかを判断することができる。 等価インピーダンスが正となる事故点が多いほど, 正の 等価インピーダンスの大きさが小さいほどよい設置点と なる。

〈3・3〉 限流器等価インピーダンスに上限がある場合の 設置点選定 限流器等価インピーダンスに上限のある 場合には, 事故点と限流器設置点の組合せにより, 事故 電流を要求される短絡電流值まで限流できない場合が生 じる。このような場合を扱うために，限流しきれない電 流值（図 4 の逸脱量）を評価し，これを“最も効果的な 設置点”の選定基準として用いることとした。

限流器等価インピーダンスに上限がある場合の最も効 果的な設置点の選定アルゴリズムを図 5 に示す。

ここで, ある事故点 $i$ と限流器設置点（ブランチ $k-l$ と する）の組合せを考えた場合に，逸脱量 $I_{E R R}$ は， $I_{F}$ を 要求される短絡電流值, $Z_{\max }$ を限流器等価インピーダン ス上限值, $Z_{(s)}$ を限流器設置点ブランチ $s$ のイン゚ーダ ンスとして,(13),(14) 式で $\Delta Z=Z_{\max }$ とすることに より,

$$
\begin{aligned}
I_{E R R} & =\frac{V_{i}}{Z_{i i}+\Delta Z_{i i}}-I_{F} \\
& =\frac{\left(C_{1}+Z_{p}\right) V_{i}}{\left(C_{1}+Z_{p}\right) Z_{i i}-C_{2}}-I_{F} \\
Z_{p} & =-\frac{Z_{(s)}\left(Z_{(s)}+Z_{\max }\right)}{Z_{\max }}
\end{aligned}
$$

となる。

図 5 に示すように，提案手法は短絡電流の抑制が必要 な事故点と限流器設置点の候補の組合せの全てについて, 必要となる等価インピーダンスと逸脱量を評価すること になる。ただし，〈3・2〉節および本節に示したように，必

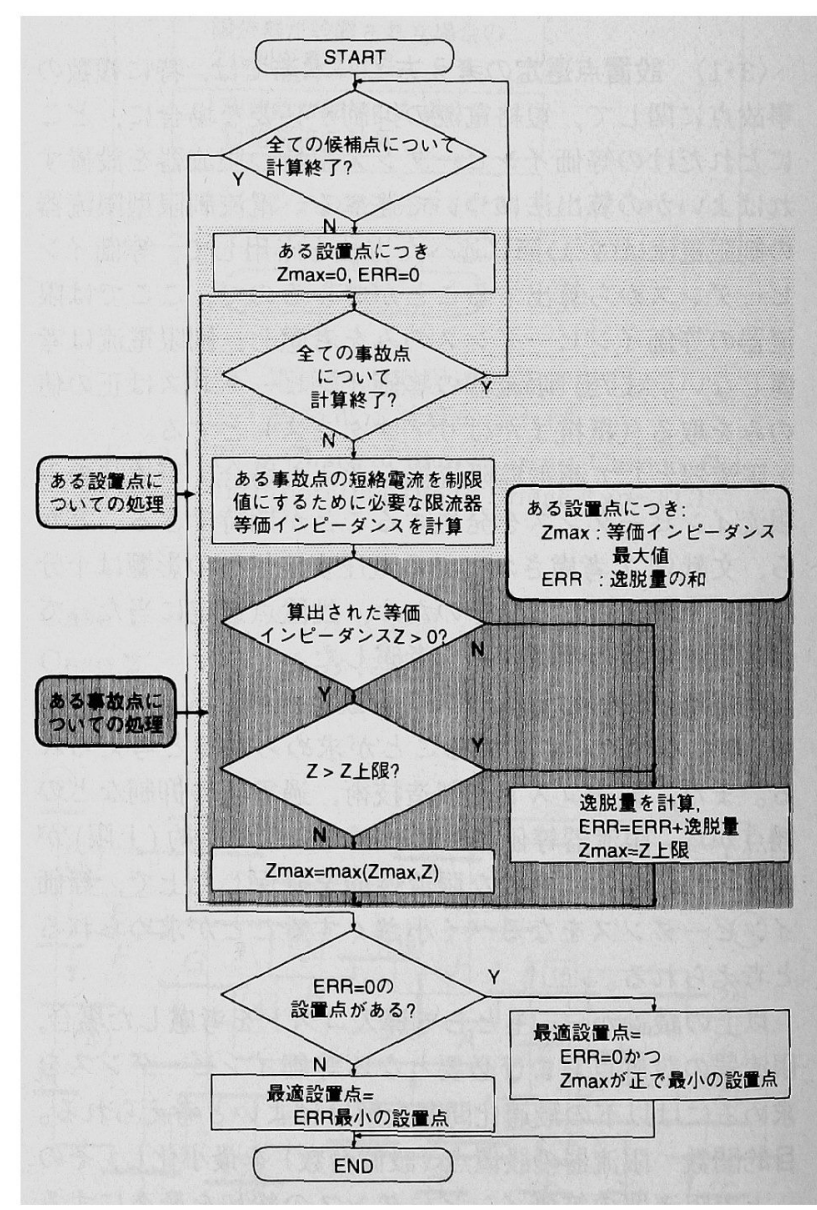

図 5 最も効果的な設置点の選定アルゴリズム

Fig. 5. Flow Chart of Location Selection of FCL with Limitation of Equivalent Impedance 
表 2 限流器の設置・非設置による 短絡電流の変化

Table 2. Fault Currents with/without FCL

\begin{tabular}{|c|c|c|}
\hline \multirow{2}{*}{$\begin{array}{l}\text { 阽点 } \\
\text { ノード }\end{array}$} & \multicolumn{2}{|c|}{ 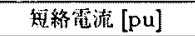 } \\
\hline & 非喑筇㭙 & 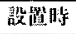 \\
\hline 16 & 28.052 & 25.000 \\
\hline 17 & 27.641 & 24.532 \\
\hline 3 & 26.754 & 24.474 \\
\hline 2 & 26.277 & 24.426 \\
\hline 18 & 25.942 & 23.423 \\
\hline 15 & 25.829 & 22.935 \\
\hline 24 & 25.766 & 22.655 \\
\hline 4 & 25.571 & 23.553 \\
\hline 14 & 25.350 & 23.231 \\
\hline
\end{tabular}

要となる等価インピーダンスの算出および逸脱量の計算 はごく簡単な計算で可能である。したがって，大規模系 統においても実用的な時間で設置点の選定を行うことが できる。

\section{$\langle 3 \cdot 4\rangle$ 数值例}

$\langle 3 \cdot 4 \cdot 1\rangle$ 等価インピーダンスの上限がない場合 こ こでは，まずく3・2〉節に示した手法の有効性を検証するた め，限流器等価インピーダンスに上限のない場合を考え る。モデル系統として，図 3 の New England 系統を用い る。ここでは全てのノードに対し，短絡電流が $25.0[\mathrm{pu}]$ 以 下となるように限流器を設置するものとする。限流器非 設置の場合の 3LS 事故時の短絡電流を計算すると, 短絡

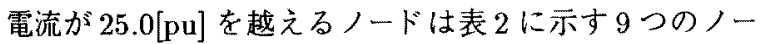
ドとなる。図 3 ではこれらのノードの番号を四角で囲っ てある。図3からわかるように，これらのノードは系統 内に広く分布しており，どこに限流器を設置すればよい かの判断は容易ではない。

ここで, 系統内の送電線ブランチを設置点の候補とし て，〈3・2〉節に述べた方法で必要となる限流器等価イン ピーダンスを計算すると表 3 のようになる。ただし，限 流器は等価インピーダンスとしてリアクタンス分のみを 持つものとした。表 3 で”一”となっている欄は得られた 等価インピーダンスが負となる場合である。また,"一” となる欄が多いブランチは省略してある。

表 3 の結果から Dに限流器を設置した場合, 全ての ノードの短絡電流を $25.0[\mathrm{pu}]$ 以下とすることが可能であ り，この設置点が最適な設置点となる。この場合の必要 となる等価インピーダンスは, 表 3 で $D$ の列での最大と なる $0.25607[\mathrm{pu}]$ となる。

$D に X=0.25607[\mathrm{pu}]$ の限流器を設置した場合と非設 置の場合の, 各ノードでの $3 \mathrm{LS}$ 事故時の短絡電流の比較 を表 2 に示す。設置時には全てのノードに対して，短絡 電流が 25.0[pu] 以下となることがわかる。

$\langle 3 \cdot 4 \cdot 2\rangle$ 等価インピーダンスに上限がある場合 次 に，限流器の等価インピーダンスの最大値を $0.05[\mathrm{pu}]$ と する。〈3・3〉節に述べた手法により, 得られた限流器設置 点と限流器等価インピーダンスを表 4 に示す。
表 4 限流器設置点の比較

Table 4. Comparison of FCL Configurations

\begin{tabular}{|c|c|c|}
\hline & 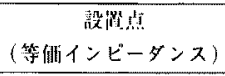 & $\begin{array}{l}\text { 等何インピー } \\
\text { ダンスの盉 }\end{array}$ \\
\hline 提督法 & $\begin{array}{l}A(X=0.0500) \\
C(X=0.0291)\end{array}$ & 0.0791 \\
\hline 樶通設潖点 & $\begin{array}{l}A(X=0.0490) \\
C(X=0.0300)\end{array}$ & 0.0790 \\
\hline
\end{tabular}

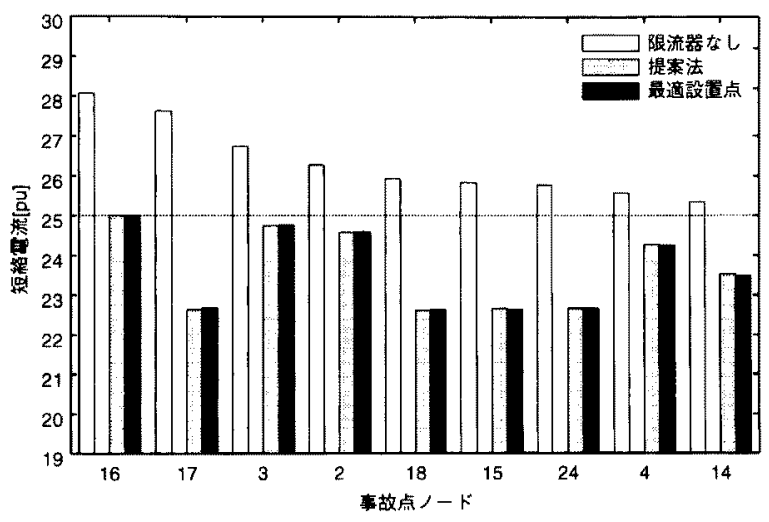

図 6 短絡電流の比較

Fig.6. Comparison of Fault Currents

提案するアルゴリズムによって得られる限流器設置点 の最適性は，保証されない。比較のため，モデル系統で 限流器等価インピーダンスの和が最小となる組合せを， 実際に限流器を設置したと仮定して短絡電流計算を行う ことにより探索した結果, 得られた最適設置点を表 4 に 示す。限流器設置点数が最小であるのは自明であるため, 設置点数は 2 筒所に固定して，探索をおこなった。その 結果, 561 通りの限流器の設置パターンに対しての短絡 電流計算が必要となり，その上，等価インピーダンスの 和の最小値の探索のために，さらに試算が必要となる。 これに対し，提案法では短絡電流計算の数倍の処理時間 で，効率良く設置点を算出することができる。

表 4 から提案法による設置点と最適設置点の限流器設 置筒所は同じであり，等価インピーダンスの和もほとん ど差がないことがわかる。限流器を設置した場合の短絡 電流を比較すると図 6 からかかる通り，ほとんど両者に 差がない。以上のことから，提案法により得られた限流器 設置点は最適な設置点とほほ同等のものであるといえる。

\section{4. まとめ}

本稿では, 短絡電流計算への電流制限型限流器の組み 込みと, 短絡電流低隇のための限流器の設置点について 検討を行なった。

短絡電流計算への電流制限型限流器の組み込みについ ては, 電流制限型限流器の等価インピーダンスを動作条 件およびネットワークのインピーダンスから簡単な計算 
表 3 必要となる限流器等価インピーダンス

Table 3. Required Impedance of FCL

\begin{tabular}{c|c|c|c|c|c|c|c|c|c}
\hline 設置点 & \multicolumn{9}{|c|}{ 每ランチ 絡霓流軽減対象ノード } \\
\cline { 2 - 10 } & 2 & 3 & 4 & 14 & 15 & 16 & 17 & 18 & 24 \\
\hline$A$ & 0.03931 & 0.05365 & - & - & 0.03389 & 0.17130 & 0.01727 & 0.00847 & 0.01276 \\
$B$ & - & - & 0.01634 & 0.00421 & 0.00305 & - & - & - & 0.04264 \\
$C$ & - & - & 0.01634 & 0.00421 & 0.01321 & - & - & - & 0.04264 \\
$D$ & 0.12185 & 0.14655 & 0.03520 & 0.01884 & 0.03465 & 0.25607 & 0.17599 & 0.04901 & 0.02866 \\
$F$ & 0.01425 & 0.02866 & 0.02394 & 0.01851 & 0.12308 & - & - & 0.03809 & 0.15279 \\
$E$ & 0.02818 & - & 0.21065 & 0.16766 & - & - & - & - & - \\
$G$ & 0.17893 & 0.05351 & 0.00686 & 0.00892 & - & - & - & 0.13159 & - \\
$H$ & 0.22625 & 0.03788 & 0.11261 & - & - & - & 0.28405 & 0.00924 & 0.08869 \\
$I$ & 0.22625 & 0.03788 & 0.11261 & - & - & - & 0.28405 & 0.00481 & 0.08869 \\
$J$ & - & - & - & 4.89917 & 0.53638 & - & - & 0.93486 & 0.13536 \\
$K$ & - & - & - & 4.89927 & 0.53638 & - & - & 0.93486 & 0.13536 \\
\hline
\end{tabular}

で得ることができ，電流制限型限流器による限流効果を 効率良く計算できることを明らかにした。

電流制限型の限流器として, 例えば整流器型限流器を 考えた場合，〈2・1〉節に述べた限流比 $\alpha$ が複素数になる。 これは限流器の動作により，電流位相が変化するためで あり，その位相変化の大きさは制限電流の大きさと系統 条件により左右される(4)。限流器のタイプにより，限流 比にどのような条件が生じるかを明らかにし，手法に反 映させていくことが，今後の課題の一つである。

限流器の設置点については，短絡電流低減のために必 要となる等価インピーダンスを用いて，簡単な論理によ り，効果的な設置点を選定できることを明らかにした。 その際，等価インピーダンスの上限値などの現実的な制 約条件を考慮することが可能であることを示した。本稿 では短絡電流の低減を目的としたが, 遮断器の遮断責務 を低減することを目的とした定式化も同様に可能である。

提案法は設置点の最適性を保証するものではないが, 数値例を用いて，提案手法により得られた設置点が，限 流器設置点数の最小化と限流器等価インピーダンスの和 の最小化という観点から，ほほ最適なものであることを 示した。系統に限流器を設置することにより, 系統内の 全ての事故点での短絡電流は必ず減少する, すなわち短 絡電流の低減という観点からは, 限流器の設置によるト レードオフの発生はない。このことから，提案手法のよ うな単純なアルゴリズムを用いても最適解に十分近い解 が得られるものと考えられる。なお，電流の回り込みに よって, かえって限流器非設置のブランチでの短絡時電 流が増加することがあるのは，〈2・2〉節での例に示した通 りである。

本稿での検討は, 1 節に述べたように, 短絡電流計算 をベースとしており, 限流器の動作完了に至るまでの過 渡状態の挙動（例えば過渡的な過電流や最終インピーダ ンスに達するまでの過電圧の発生の有無など）は考慮し ていない。したがって, 本稿の論理で求まる限流器設置 点は，その候補点となるものと考えるべきである。

限流器の詳細な動作特性の解析により，本稿では考慮
しなかった制約条件が明らかとなる可能性があり，また， 系統運用上の種々の制約も考慮する必要があると考えら れる。これらの制約は現段階では必ずしも明確なもので はないため，本稿では考慮しなかった。これらの制約を 考慮した，より現実的な設置点選定にあたっては，最適化 手法の利用を必要とする場合もありうるものと思われる。

最後に，本研究を進めるにあたり有益なご助言をいただ いた電力中央研究所 高橋一弘 理事ならびに谷口治人電 カシステム部長に感謝の意を表します。

(平成 11 年 2 月 19 日受付, 同 11 年 7 月 30 日再受 付）

\section{文献}

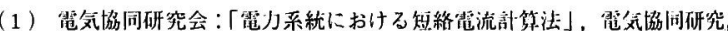
20, 6 (昭 39-8)

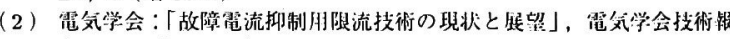
告, 709, (平 11-1)

(3) 例之ば，NEDO：「超需導電力応用技術開発 トータルシステム等の研 究導入効果の調查研究」(平 7-3)

(4) H. Kameda and H. Taniguchi: "Setting Method of Specific Parameters of a Superconducting Fault Current Limiter Considering the Operation of Power System Protection", IEEE Trans. on Applied Superconductivity, 1999 (to be published)

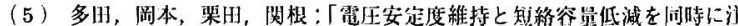
目した系統構成検討手法」, 雱学論 B, 116 ( 1 \% 8-12)

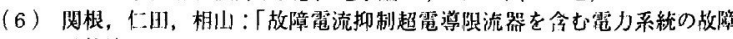
計算法」，電学論 $\mathrm{B}, 113$ (平 5-5)

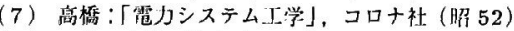

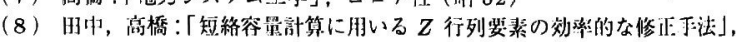
需学䈁 B, $113($ 平 5-2)

永田真 走員) 昭和 43 年 11 月 30 日生。平成 3 年 3 月

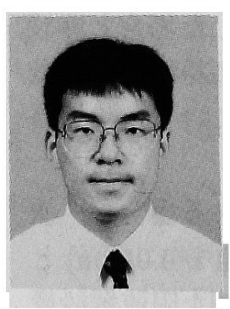
東京大学工学部電気工学科卒業。8 年 3 月同大学 大学院工学系研究科博士課程修了。博士 (工学)。 同年 4 月（財）電力中央研究所入所。現在に至る。 主に電力系統の解析に関する研究に従事。 
田中和幸（正員）昭和 26 年 12 月 30 日生。76 年 3 月九 州大学大学院修士課程 (電気工学) 修了。同年 4 月 (財) 電力中央研究所入所。主として電力系統 の計画・運用・解析に関する研究に従事。 81 年 8 月 82 年 9 月米国テキサス大学客員研究員。91 年 10 月 $~ 92$ 年 7 月九州工科大学客員助教授。工 学博士。 